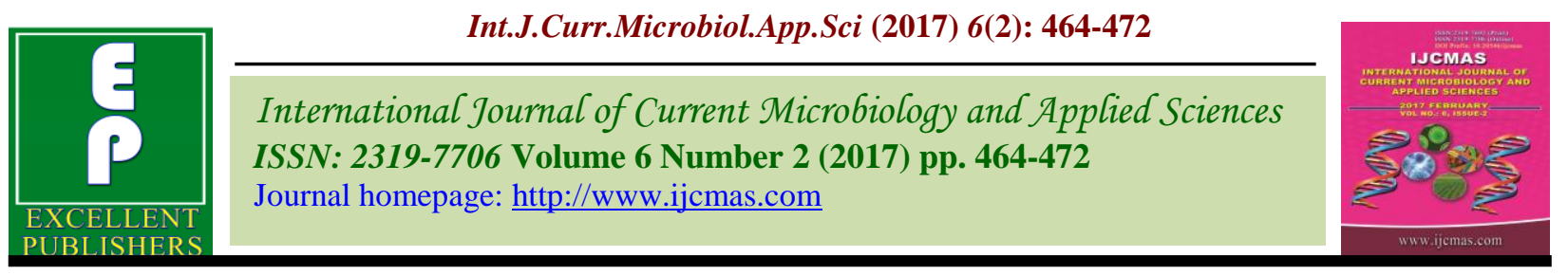

Original Research Article

http://dx.doi.org/10.20546/ijcmas.2017.602.052

\title{
Effect of Washing and Drying Methods in the Quality of Nutmeg
}

\author{
S. Naveen Kumar ${ }^{1}$, A. Srinivasulu ${ }^{2}$, P. Jacob John ${ }^{1}$ and C.H. Bharghavarami Reddy ${ }^{2}$ \\ ${ }^{1}$ Department of Processing Technology, College of Horticulture, Vellanikkara, \\ Thrissur -680 656, India \\ ${ }^{2}$ Krishi Vigyan Kendra, Kalikiri, Acharya N G Ranga Agricultural University, Chittoor District, \\ Andhra Pradesh -517 234, India \\ *Corresponding author
}

A B S T R A C T

To study the effect of washing and dying methods in the quality of nutmeg this experiment was conducted at the Department of Processing Technology and Department of Plantation

Keywords Crops and Spices, College of Horticulture, Vellanikkara, Thrissur, during 2012-2013. In this study an attempt has been made to develop a suitable washing and drying technique for both mace and nut of nutmeg (Myristica fragrans Houtt.). In mace and nut, high

Quality of nutmeg, Myristica fragrans, Actinomycetes, Highest oleoresin, Oil content.

\section{Article Info}

\section{Accepted:}

15 January 2017 Available Online: 10 February 2017 microbial load $\left(35 \times 10^{6} \mathrm{cfu} / \mathrm{g}\right.$ bacteria, $14 \times 10^{3} \mathrm{cfu} / \mathrm{g}$ fungi and $6.0 \times 10^{5} \mathrm{cfu} / \mathrm{g}$ actinomycetes) was observed in fallen nutmeg without mace, highest recovery percentage (48.50\% and $69.56 \%$ for mace and nut respectively in harvested nutmeg; and $48.60 \%$ and $70.16 \%$ for mace and nut respectively in fallen nutmeg) was recorded in sun dried samples, residual moisture content was high in sun dried nutmeg, mace dried in a mechanical drier showed better colour than other methods of drying, drying of mace under close vicinity of 60 watt burning bulbs was observed to be faster compared to other methods of drying, harvested nutmeg mace showed initial faster rate of drying compared to that of fallen nutmeg mace, and least microbial population was noticed in mechanically dried samples $\left(0.3 \times 10^{6} \mathrm{cfu} / \mathrm{g}\right.$ bacteria, $0.6 \times 10^{3} \mathrm{cfu} / \mathrm{g}$ fungi and zero actinomycetes in harvested nutmeg mace, highest oleoresin, oil content and total sensory score was recorded in mechanical dying.

\section{Introduction}

India is also known as 'Land of Spices', where each state cultivates one or the other spices and Indians use them generously in their culinary preparations as well as in traditional medicines. Only nine per cent of our spice production is exported to more than 100 countries and remaining are consumed internally. India commands a formidable position in the world spice trade with 45 per cent share in volume and 30 per cent in value. Nutmeg (Myristica fragrans Houtt.) is unique among the tree spice plants as it produces two commercial spice products namely, nutmeg and mace. It belongs to the family Myristicaceae, comprising of 19 genera and about 400 species. Nutmeg is the dried seed, while mace is the aril covering the outer surface of the seed. The yield of the mace is about 15 per cent that of nutmeg and it is more expensive among the two spices. The spice is widely used as a condiment and also in medicine. In India nutmeg and mace are used more as drugs than as condiments due to their valuable medicinal properties. Mace is 
chewed for masking foul breath (Pruthi, 1979). Nutmeg the "two in one spice" is valued for its flavouring and medicinal properties. It is native of Moluccas Island and in India it is cultivated throughout Kerala, parts of Tamil Nadu, Karnataka, Goa, Assam and Andaman and Nicobar Islands in an area of 15,131 ha with a production 11,424 tonnes of spice. India also imports 1,325 tonnes of nutmeg and 265 tonnes of mace (Haldankar and Rangwala, 2009).

Dried nutmeg and mace are of great importance in international trade and are used in the preparation of its extractives and volatile oils. The pale yellow essential oil which is volatile fraction obtained by steam distillation is used as a flavouring essence and in perfumery. Drying to optimum moisture level without losing the inherent qualities especially the colour is a prerequisite for long storage and better price. Colour plays an important role in deciding the commercial value of mace and it has been established that its scarlet red colour is due to the pigment lycopene (Gopalakrishnan et al., 1980). The keeping quality of spices depends much on drying and moisture content should be kept between 10 to 12 per cent for most of the spices for better storage (Pruthi and Krishnamurthy, 1985). Even one percentage more than critical moisture level may affect the quality of mace. The most important parameter in drying is the temperature and time of exposure and this may vary with the end use of the product. During drying, the mace loses about 60 per cent of its weight as moisture (Gopalakrishnan, 1992). If drying is delayed, mace becomes highly susceptible to mould and insect contamination.

The appearance, the contents of volatile oil and oleoresin, the pungency level and a subjective assessment of the aroma and flavour are important in the quality evaluation of dried nutmeg and mace. The relative importance of these aspects is dependent upon the end use of the spice. A number of factors at both the preharvest and post harvest stages can have a significant influence on the quality of the dried product. After the processing of spices, proper packaging and storage is important as the spices and spice products are hygroscopic, which results in absorption of moisture and as a result of this, the product becomes lumpy and microbial load will also increase thus decreasing the product quality. Frequent aflatoxin contamination due to Aspergillus sp. is found in many spices like nutmeg, chillies and the products exported were being rejected by the importing countries like European Union. In view of these problems, it was proposed to carry out a study entitled "Washing and Drying studies in nutmeg (Myristica fragrans Houtt.)".

\section{Materials and Methods}

The present investigation on "Drying and storage studies in nutmeg (Myristica fragrans Houtt.) was carried out during 2012-2013 at the Department of Processing Technology and Department of Plantation Crops and Spices, College of Horticulture, Vellanikkara, Thrissur located at $10^{\circ} 32^{\prime} \mathrm{N}$ latitude, $70^{\circ} 10^{\prime}$ E longitude and $22.25 \mathrm{~m}$ above mean sea level. The area has a tropical monsoon climate.

In this study an attempt has been made to develop a suitable washing and drying technique for both mace and nut of nutmeg (Myristica fragrans Houtt.). The nutmeg fruits (both freshly harvested and fallen) were collected in morning hours from Banana Research Station, Kannara, Thrissur.

The outer fleshy pericarp was removed and the whole nut with and without mace were subjected to different pretreatments along with control and subjected to microbial estimation of bacteria, fungi and 
actinomycetes. Sample size was 25 nutmegs per treatment. Control: Initial count, $\mathrm{T}_{1}$ : Washing in plain running water for two minutes, $\mathrm{T}_{2}$ : Washing in luke warm water containing 100 ppm chlorine for two minutes, $\mathrm{T}_{3}$ : Washing in luke warm water containing $1000 \mathrm{ppm}$ alum for two minutes, $\mathrm{T}_{4}$ : Blanching in hot water at $75^{\circ} \mathrm{C}$ to $80^{\circ} \mathrm{C}$ for two minutes, Best pretreatment based on the microbial load, colour and appearance was selected for further drying studies. Two materials viz. mace alone and nut alone were used for drying studies.

For drying studies the experiment was laid out in a Completely Randomized Design (CRD) with three replications of $100 \mathrm{~g}$ of mace and $200 \mathrm{~g}$ of whole nut without mace. Treatment consisted $\mathrm{T}_{1}$-Sun drying, $\mathrm{T}_{2}$-Oven drying, $\mathrm{T}_{3^{-}}$ Bulb drying, $\mathrm{T}_{4}$-Mechanical drying and Control-Nutmeg without pretreatment but mechanically dried. Observations on both physical and chemical changes after drying were taken.

\section{Results and Discussion}

\section{Initial microbial load of nutmeg}

The results indicated that significant difference exists between the harvested and fallen nutmeg with or without mace and among them high microbial load $\left(35 \times 10^{6}\right.$ $\mathrm{cfu} / \mathrm{g}$ bacteria, $14 \times 10^{3} \mathrm{cfu} / \mathrm{g}$ fungi and $6.0 \times 10^{5}$ cfu/g actinomycetes) was observed in $\mathrm{T}_{4}$ (fallen nutmeg without mace) and least microbial load $\left(5.3 \times 10^{6} \mathrm{cfu} / \mathrm{g}\right.$ bacteria, $4.0 \times 10^{3} \quad \mathrm{cfu} / \mathrm{g}$ fungi, $1.3 \times 10^{5} \mathrm{cfu} / \mathrm{g}$ actinomycetes) was observed in $\mathrm{T}_{2}$ (harvested nutmeg without mace). The high microbial load observed in fallen nutmeg could be due to its contact with the wet soil (Table 1).

\section{Microbial load after pretreatments}

Significant difference was observed among the pretreatments. Pretreatment with luke warm water containing 1000 ppm alum was recorded to be the best as it showed least microbial load followed by treatment with luke warm water containing 100 ppm chlorine (Table 2).

\section{Changes in colour and appearance due to pretreatments}

No significant difference was observed among the pretreatments with respect to colour and appearance of nutmeg, yet the pretreated nutmeg showed better appearance and colour than the nutmeg without pretreatment in both harvested and fallen nutmeg. Between harvested and fallen nutmeg, harvested nutmeg was superior to fallen nutmeg with respect to colour and appearance as it was free from adherent soil.

\section{Recovery percentage and Residual moisture}

In nutmeg, significant difference was observed among the drying methods and highest recovery percentage $(48.50 \%$ and $69.56 \%$ for mace and nut respectively in harvested nutmeg; and $48.60 \%$ and $70.16 \%$ for mace and nut respectively in fallen nutmeg) was recorded in $\left(\mathrm{T}_{1}\right)$ sun dried samples followed by oven dried samples $\left(\mathrm{T}_{2}\right)$.

As the mace is having delicate structure and more surface area than nut, least recovery percentage was noticed in it. The heat transfer and mass transfer during drying will depend basically on the increased surface area. Higher surface area leads to maximum escape of moisture leading to low recovery. Higher recovery percentage of nut was due to lower water content in it (wet basis) but higher bio mass.

Residual moisture content was high in sun dried nutmeg and it reflects the microbial quality of a dried product. The least residual moisture percentage of mace dried in a mechanical drier was due to low recovery which was explained above. These findings 
are similar to that of Gauniyal et al., (1988) who found that roots and whole plant samples with thicker texture and lesser area exposed to a drying agent, recorded more moisture in shade and sun drying and lower moisture for mechanical drying. Manjusha (2012) also reported similar results in the case of drying of Kizharnelli (Table 3).

\section{Colour changes due to drying}

Colour is one of the important attributes of any dried material. During drying, the initial scarlet red colour of mace was changed to light red to reddish brown colour. Visual assessments of the colour of dried materials were carried out. It was observed that mace dried in a mechanical drier showed better colour than other methods of drying. In case of drying under 60 watt burning bulbs slight bleaching of colour was observed owing to its high temperature of 72 to $76^{\circ} \mathrm{C}$ during drying, whereas oven dried mace showed dark brown colour. Prolonged exposure of materials to sunlight or to higher temperature will result in change in colour of the product. Bulb dried mace showed bleached appearance because of high temperature during drying whereas country oven dried mace showed darkened appearance because of smoke coming out from drier. But good orange red colour retention was found in mechanically dried nutmeg. Slight mould growth was observed in sun dried mace because of slow drying rate and problem of rewetting. These results are in accordance with the findings of Chikkanna (2008) who reported that mace dried in a developed drier (mechanical drier) showed better appearance than sun dried mace and the later showed mould growth also.

\section{Drying rate}

In the four methods of drying, drying of mace under close vicinity of 60 watt burning bulbs was observed to be faster compared to other methods of drying and slow drying rate was observed in sun drying. The trend was followed both in harvested nutmeg mace and fallen nutmeg mace.

Sun drying of mace took 16 hours for attaining constant weight, whereas other methods took only seven hours for attaining constant weight. Among all the methods, mechanical drying of mace resulted in uniform colour.

In case of drying nut, the least time taken for drying was in oven drying (14 hours) followed by mechanical drying and bulb drying (18 hours each). Longest drying time was recorded in sun drying 56 hours (8 days $X 7$ hours per day). The trend was followed both in harvested nutmeg as well in fallen nutmeg.

Drying rate influences the efficiency of a drying method. Drying rate depends on the drying temperature, initial moisture content and texture of the plant material. Harvested nutmeg mace showed initial faster rate of drying compared to that of fallen nutmeg mace. Higher temperature and higher surface area will result in higher rate of drying. This is the reason why faster rate of drying was recorded in nutmeg dried under burning bulbs at $72^{\circ} \mathrm{C}$ to $76^{\circ} \mathrm{C}$ followed by oven drying at $65^{\circ} \mathrm{C}$ to $68^{\circ} \mathrm{C}$. The slower drying rate of nut was due to its less moisture content and also the hard seed shell hinders the process of drying. These results are in accordance with the findings of Gopalakrishnan et al., (1980) who reported that sun drying of mace takes about 12 to 16 hours under open sun but only five to six hours in mechanical drying. Jayashree et al., (2010) also reported that drying of mace in an air flow drier took 300 to 330 minutes to dry to a safer moisture level of six per cent. Yuvaraj (2007) reported that Wedelia chinensis, when dried mechanically has the highest rate of drying compared to sun and shade drying. Padmapriya et al., (2009) also reported that sun drying of Tinosporia cordifolia required longer period than 
mechanical drying and the highest drying rate was observed in mechanical drying of smallest stem bits. Similar results were also obtained by Mehta et al., (2005) (Table 4a, b).

\section{Microbial population of nutmeg dried under different drying methods}

When drying methods were compared for microbial population, least microbial growth was observed in bulb dried and mechanically dried samples than other methods. The control samples (nutmeg without pretreatment but mechanically dried) showed maximum microbial population $\left(1.6 \times 10^{6} \mathrm{cfu} / \mathrm{g}\right.$ bacteria, $1.6 \times 10^{3} \mathrm{cfu} / \mathrm{g}$ fungi and $0.6 \times 10^{5} \mathrm{cfu} / \mathrm{g}$ actinomycetes in harvested nutmeg mace; $4.6 \times 10^{6} \mathrm{cfu} / \mathrm{g}$ bacteria, $3.3 \times 10^{3} \mathrm{cfu} / \mathrm{g}$ fungi and $1.6 \times 10^{5} \mathrm{cfu} / \mathrm{g}$ actinomycetes in fallen nutmeg mace); least microbial population was noticed in mechanically dried samples $\left(0.3 \times 10^{6} \mathrm{cfu} / \mathrm{g}\right.$ bacteria, $0.6 \times 10^{3} \mathrm{cfu} / \mathrm{g}$ fungi and zero actinomycetes in harvested nutmeg mace; $1.3 \times 10^{6} \mathrm{cfu} / \mathrm{g}$ bacteria, $1.6 \times 10^{3} \mathrm{cfu} / \mathrm{g}$ fungi and $0.3 \times 10^{5} \mathrm{cfu} / \mathrm{g}$ actinomycetes in fallen nutmeg mace). High microbial population in control (nutmeg without pretreatment but mechanically dried) was probably due to high initial microbial load. This clearly explains the importance of pretreatment in reducing the initial microbial load of nutmeg. Higher the residual moisture content in the products higher will be the microbial population. This is the reason why nutmeg dried under sun showed higher microbial population than other methods. More over during sun drying, nutmeg is exposed to outside environment which ultimately resulted in the contamination of the product. Mechanically dried and bulb dried nutmeg showed least microbial population because the drying chamber is closed and free from extraneous contaminants. The high microbial population of nutmeg without pretreatment could be due to the fact that it contains high initial microbial population. Fallen nutmeg samples showed higher microbial population than harvested nutmeg samples because initially they contained higher microbial population. This result is in accordance with the findings of Chikkanna (2008) who reported that sun dried nutmeg showed mould growth. Joy (2000) also reported that extraneous matter, insect infected, whole insects dead and mould content were very high in commercially dried nutmeg (sun dried) whereas it was absent in solar tunnel dried nutmeg (Table 5).

\section{Oleoresin and oil content of nutmeg dried under different drying methods}

When drying methods were compared for oil and oleoresin content of harvested nutmeg, it was recorded that nutmeg dried in a mechanical drier $\left(\mathrm{T}_{4}\right)$ yielded higher oil content 8.4 per cent and 8.06 per cent in mace and nut respectively. Similarly higher oleoresin content was observed in mechanically dried nutmeg $\left(\mathrm{T}_{4}\right) 22.40$ per cent and 29.09 per cent in mace and nut respectively. Similar results were observed in fallen nutmeg also. On comparison of harvested nutmeg with fallen nutmeg, harvested nutmeg showed slightly higher oil and oleoresin content than fallen nutmeg (Table 6).

Table.1 Microbial population of nutmeg before pretreatments

\begin{tabular}{|l|c|c|c|}
\hline \multirow{2}{*}{\multicolumn{1}{|c|}{ Sample }} & \multicolumn{3}{c|}{ Total microbial count in cfu/g } \\
\cline { 2 - 4 } & Bacteria $\left(\mathbf{x ~ 1 0} \mathbf{1 0}^{\mathbf{6}}\right)$ & Fungi $\left(\mathbf{x ~ 1 0} \mathbf{3}^{\mathbf{3}}\right)$ & Actinomycetes $\left(\mathbf{x ~ 1 0}\right.$ ) $^{\mathbf{5}}$ ) \\
\hline Harvested nutmeg with mace & $6.3^{\mathrm{c}}$ & $5.3^{\mathrm{bc}}$ & $2.6^{\mathrm{c}}$ \\
\hline Harvested nutmeg without mace & $5.3^{\mathrm{c}}$ & $4.0^{\mathrm{d}}$ & $1.3^{\mathrm{d}}$ \\
\hline Fallen nutmeg with mace & $28.0^{\mathrm{b}}$ & $8.6^{\mathrm{b}}$ & $4.6^{\mathrm{b}}$ \\
\hline Fallen nutmeg without mace & $35.0^{\mathrm{a}}$ & $14^{\mathrm{a}}$ & $6.0^{\mathrm{a}}$ \\
\hline
\end{tabular}


Table.2 Microbial population of harvested and fallen nutmeg after pretreatments

\begin{tabular}{|c|c|c|c|c|c|c|}
\hline \multirow{3}{*}{ Treatments } & \multicolumn{6}{|c|}{ Total microbial count in $\mathrm{cfu} / \mathrm{g}$} \\
\hline & \multicolumn{3}{|c|}{ Harvested nut with mace } & \multicolumn{3}{|c|}{ Harvested nut without mace } \\
\hline & $\begin{array}{c}\text { Bacteria } \\
\left(\times 10^{6}\right)\end{array}$ & $\begin{array}{l}\text { Fungi } \\
\left(\times 10^{3}\right)\end{array}$ & $\begin{array}{c}\text { Actinomycetes } \\
\left(\times \mathbf{1 0}^{5}\right)\end{array}$ & $\begin{array}{c}\text { Bacteria } \\
\left(x 1^{6}\right)\end{array}$ & $\begin{array}{l}\text { Fungi } \\
\left(x \mathbf{1 0}^{\mathbf{3}}\right)\end{array}$ & $\begin{array}{c}\begin{array}{c}\text { Actinomycetes } \\
\left(\mathbf{x} \mathbf{1 0}^{5}\right)\end{array} \\
\end{array}$ \\
\hline Control & $6.3 \mathrm{a}$ & $5.3 \mathrm{a}$ & $2.6 \mathrm{a}$ & $5.3 \mathrm{a}$ & $4.0 \mathrm{a}$ & $1.3 \mathrm{a}$ \\
\hline $\begin{array}{c}\mathrm{T} 1 \\
\text { (Running water) }\end{array}$ & $\begin{array}{c}4.0 \mathrm{~b} \\
(36.84)\end{array}$ & $\begin{array}{c}4.0 \mathrm{~b} \\
(25.00)\end{array}$ & $\begin{array}{c}1.00 \mathrm{~b} \\
(62.50)\end{array}$ & $\begin{array}{c}2.6 b \\
(50.00)\end{array}$ & $\begin{array}{c}2.6 \mathrm{ab} \\
(33.33)\end{array}$ & $\begin{array}{c}0.3 \mathrm{~b} \\
(75.00)\end{array}$ \\
\hline $\begin{array}{c}\mathrm{T} 2 \\
\text { (Chlorine water) }\end{array}$ & $\begin{array}{c}2.6 b \\
(57.89)\end{array}$ & $\begin{array}{c}0.3 c \\
(93.75)\end{array}$ & $\begin{array}{c}0.3 \mathrm{~b} \\
(87.5)\end{array}$ & $\begin{array}{c}1.6 b \\
(68.75)\end{array}$ & $\begin{array}{c}0.0 \mathrm{c} \\
(100.0)\end{array}$ & $\begin{array}{c}0.0 \mathrm{~b} \\
(100.00)\end{array}$ \\
\hline $\begin{array}{c}\text { T3 } \\
\text { (Alum water) }\end{array}$ & $\begin{array}{c}2.0 \mathrm{~b} \\
(68.42)\end{array}$ & $\begin{array}{c}0.0 \mathrm{c} \\
(100.0)\end{array}$ & $\begin{array}{c}0.3 \mathrm{~b} \\
(87.5)\end{array}$ & $\begin{array}{c}1.3 \mathrm{~b} \\
(75.00) \\
\end{array}$ & $\begin{array}{c}0.0 \mathrm{c} \\
(100.0)\end{array}$ & $\begin{array}{c}0.0 b \\
(100.00)\end{array}$ \\
\hline \multirow[t]{2}{*}{$\begin{array}{c}\mathrm{T} 4 \\
\text { (Blanching) } \\
\end{array}$} & $\begin{array}{c}2.6 \mathrm{~b} \\
(57.89) \\
\end{array}$ & $\begin{array}{c}3.0 \mathrm{~b} \\
(43.75) \\
\end{array}$ & $\begin{array}{c}0.3 b \\
(87.5) \\
\end{array}$ & $\begin{array}{c}1.6 \\
(68.75) \\
\end{array}$ & $\begin{array}{c}2.00 \mathrm{~b} \\
(50.00) \\
\end{array}$ & $\begin{array}{c}0.3 b \\
(100.00) \\
\end{array}$ \\
\hline & \multicolumn{3}{|c|}{ Fallen nut with mace } & \multicolumn{3}{|c|}{ Fallen nut without mace } \\
\hline Control & $28.0 \mathrm{a}$ & $8.6 \mathrm{a}$ & $4.6 \mathrm{a}$ & $35.0 \mathrm{a}$ & $14 \mathrm{a}$ & $6.0 \mathrm{a}$ \\
\hline $\begin{array}{c}\mathrm{T} 1 \\
\text { (Running water) }\end{array}$ & $\begin{array}{c}9.6 b \\
(65.47)\end{array}$ & $\begin{array}{c}8.0 \mathrm{a} \\
(12.82)\end{array}$ & $\begin{array}{c}2.0 \mathrm{~b} \\
(57.14)\end{array}$ & $\begin{array}{c}10.5 b \\
(69.52)\end{array}$ & $\begin{array}{l}11.3 \mathrm{ba} \\
(21.42)\end{array}$ & $\begin{array}{c}3.0 \mathrm{~b} \\
(50.00)\end{array}$ \\
\hline $\begin{array}{c}\mathrm{T} 2 \\
\text { (Chlorine water) }\end{array}$ & $\begin{array}{c}5.0 c \\
(82.14)\end{array}$ & $\begin{array}{c}0.3 c \\
(96.15)\end{array}$ & $\begin{array}{c}1.0 \mathrm{~b} \\
(85.71)\end{array}$ & $\begin{array}{c}5.6 c \\
(83.80)\end{array}$ & $\begin{array}{c}1.3 c \\
(90.47)\end{array}$ & $\begin{array}{c}1.0 c \\
(83.33)\end{array}$ \\
\hline $\begin{array}{c}\text { T3 } \\
\text { (Alum water) }\end{array}$ & $\begin{array}{c}4.0 c \\
(85.71)\end{array}$ & $\begin{array}{c}0.3 c \\
(96.15)\end{array}$ & $\begin{array}{c}1.0 \mathrm{~b} \\
(85.71)\end{array}$ & $\begin{array}{c}4.0 c \\
(88.57)\end{array}$ & $\begin{array}{c}1.3 c \\
(90.47)\end{array}$ & $\begin{array}{c}1.3 \mathrm{bc} \\
(77.77)\end{array}$ \\
\hline $\begin{array}{c}\text { T4 } \\
\text { (Blanching) } \\
\end{array}$ & $\begin{array}{c}6.3 c \\
(77.38) \\
\end{array}$ & $\begin{array}{c}4.3 b \\
(50.00)\end{array}$ & $\begin{array}{c}1.3 b \\
(78.57)\end{array}$ & $\begin{array}{c}8.0 b c \\
(77.14) \\
\end{array}$ & $\begin{array}{c}5.6 b \\
(59.52) \\
\end{array}$ & $\begin{array}{c}2.3 b c \\
(61.11)\end{array}$ \\
\hline
\end{tabular}

Table.3 Effect of drying methods on recovery and residual moisture percentage of dried nutmeg

\begin{tabular}{|c|c|c|c|c|c|c|c|c|}
\hline \multirow{3}{*}{ Treatments } & \multicolumn{4}{|c|}{ Harvested nutmeg } & \multicolumn{4}{c|}{ Fallen nutmeg } \\
\cline { 2 - 8 } & \multicolumn{2}{|c|}{ Recovery (\%) } & \multicolumn{2}{c|}{$\begin{array}{c}\text { Residual } \\
\text { moisture (\%) }\end{array}$} & \multicolumn{2}{c|}{ Recovery (\%) } & \multicolumn{2}{c|}{$\begin{array}{c}\text { Residual } \\
\text { moisture (\%) }\end{array}$} \\
\cline { 2 - 8 } & Mace & Nut & Mace & Nut & Mace & Nut & Mace & Nut \\
\hline $\mathrm{T}_{1}$ & $48.50^{\mathrm{a}}$ & $69.56^{\mathrm{a}}$ & $9.63^{\mathrm{a}}$ & $10.23^{\mathrm{a}}$ & $48.60^{\mathrm{a}}$ & $70.16^{\mathrm{a}}$ & $10.03^{\mathrm{a}}$ & $10.43^{\mathrm{a}}$ \\
\hline $\mathrm{T}_{2}$ & $45.44^{\mathrm{b}}$ & $65.40^{\mathrm{b}}$ & $7.56^{\mathrm{b}}$ & $5.91^{\mathrm{b}}$ & $45.66^{\mathrm{b}}$ & $66.43^{\mathrm{b}}$ & $7.73^{\mathrm{b}}$ & $5.32^{\mathrm{c}}$ \\
\hline $\mathrm{T}_{3}$ & $43.98^{\mathrm{c}}$ & $64.00^{\mathrm{c}}$ & $6.80^{\mathrm{c}}$ & $5.39^{\mathrm{c}}$ & $44.16^{\mathrm{d}}$ & $65.46^{\mathrm{c}}$ & $6.88^{\mathrm{c}}$ & $5.56^{\mathrm{bc}}$ \\
\hline $\mathrm{T}_{4}$ & $44.77^{\mathrm{bc}}$ & $63.66^{\mathrm{c}}$ & $6.90^{\mathrm{c}}$ & $5.11^{\mathrm{c}}$ & $44.93^{\mathrm{c}}$ & $65.26^{\mathrm{c}}$ & $7.06^{\mathrm{c}}$ & $5.63^{\mathrm{b}}$ \\
\hline Control & $45.36^{\mathrm{b}}$ & $64.35^{\mathrm{c}}$ & $7.46^{\mathrm{b}}$ & $5.35^{\mathrm{c}}$ & $45.72^{\mathrm{b}}$ & $66.50^{\mathrm{b}}$ & $7.56^{\mathrm{b}}$ & $5.53^{\mathrm{bc}}$ \\
\hline
\end{tabular}

(Values with different superscript differ significantly)

The values represent average of three replications

$\mathrm{T}_{1}$ : Sun drying, $\mathrm{T}_{2}$ : Oven drying, $\mathrm{T}_{3}$ : Bulb drying, $\mathrm{T}_{4}$ : Mechanical drying and Control: Nutmeg without pretreatment but mechanically dried 
Table.4a Drying rate of nutmeg mace dried under different drying methods

\begin{tabular}{|c|c|c|c|c|c|c|c|c|c|}
\hline \multicolumn{10}{|c|}{ Percentage weight to original weight of Nutmeg mace } \\
\hline \multirow{2}{*}{$\begin{array}{c}\text { Duration } \\
\text { (Hours) }\end{array}$} & \multicolumn{3}{|c|}{ Harvested } & \multicolumn{3}{|c|}{ Fallen } & \multirow{2}{*}{$\begin{array}{c}\text { Duration } \\
\text { (Hours) }\end{array}$} & \multirow{2}{*}{$\frac{\text { Harvested }}{\text { SN }}$} & \multirow{2}{*}{$\begin{array}{c}\text { Fallen } \\
\text { SN }\end{array}$} \\
\hline & OD & MD & BD & OD & MD & BD & & & \\
\hline 0 & 100 & 100 & 100 & 100 & 100 & 100 & 0 & 100 & 100 \\
\hline 1 & 88.32 & 86.27 & 82.43 & 90.54 & 88.46 & 85.60 & 2 & 90.08 & 92.28 \\
\hline 2 & 71.53 & 74.16 & 70.15 & 73.35 & 75.40 & 72.35 & 4 & 81.65 & 83.50 \\
\hline 3 & 62.41 & 64.50 & 62.06 & 63.64 & 66.30 & 64.26 & 6 & 72.41 & 74.54 \\
\hline 4 & 55.47 & 56.13 & 54.96 & 57.67 & 59.13 & 56.96 & 8 & 65.42 & 67.50 \\
\hline 5 & 47.91 & 48.85 & 46.12 & 50.20 & 52.00 & 48.62 & 10 & 58.56 & 60.66 \\
\hline 6 & 45.83 & 46.16 & 44.24 & 48.00 & 48.56 & 46.45 & 12 & 52.48 & 54.70 \\
\hline 7 & 44.12 & 45.23 & 43.35 & 46.30 & 47.40 & 45.50 & 14 & 48.89 & 50.40 \\
\hline 8 & 44.12 & 45.23 & 43.35 & 46.30 & 47.40 & 45.50 & 16 & 48.20 & 50.90 \\
\hline
\end{tabular}

Table.4b Drying rate of nutmeg nut dried under different drying methods

\begin{tabular}{|c|c|c|c|c|c|c|c|c|c|}
\hline \multicolumn{10}{|c|}{ Percentage weight to original weight of Nutmeg nut } \\
\hline \multirow{2}{*}{$\begin{array}{c}\text { Duration } \\
\text { (Hours) }\end{array}$} & \multicolumn{3}{|c|}{ Harvested } & \multicolumn{3}{|c|}{ Fallen } & \multirow{2}{*}{$\begin{array}{c}\text { Duration } \\
\text { (Days) }\end{array}$} & \multirow{2}{*}{$\begin{array}{l}\text { Harvested } \\
\text { SN }\end{array}$} & \multirow{2}{*}{$\begin{array}{c}\text { Fallen } \\
\text { SN }\end{array}$} \\
\hline & OD & MD & BD & OD & MD & BD & & & \\
\hline 0 & 100 & 100 & 100 & 100 & 100 & 100.00 & 0 & 100 & 100 \\
\hline 2 & 87.23 & 95.07 & 87.66 & 86.00 & 94.07 & 89.66 & 1 & 88.86 & 90.86 \\
\hline 4 & 80.79 & 90.30 & 81.83 & 82.60 & 89.30 & 83.83 & 2 & 80.95 & 82.95 \\
\hline 6 & 75.30 & 86.30 & 76.30 & 78.80 & 85.30 & 78.30 & 3 & 76.54 & 77.54 \\
\hline 8 & 71.42 & 81.50 & 72.07 & 75.26 & 81.50 & 74.07 & 4 & 73.93 & 74.93 \\
\hline 10 & 68.34 & 77.30 & 70.16 & 72.40 & 75.40 & 71.40 & 5 & 72.38 & 73.38 \\
\hline 12 & 66.00 & 73.80 & 68.95 & 69.20 & 72.10 & 69.30 & 6 & 71.00 & 72.00 \\
\hline 14 & 64.21 & 70.40 & 67.09 & 67.30 & 69.65 & 68.40 & 7 & 69.80 & 71.10 \\
\hline 16 & 64.21 & 67.50 & 66.35 & 65.71 & 68.20 & 67.10 & 8 & 69.80 & 70.20 \\
\hline 18 & 64.21 & 65.10 & 64.30 & 65.71 & 66.32 & 65.80 & 9 & 69.80 & 70.20 \\
\hline 20 & 64.21 & 65.10 & 64.30 & 65.71 & 66.32 & 65.80 & & & \\
\hline
\end{tabular}

Table.5 Microbial population of nutmeg dried under different drying methods

\begin{tabular}{|c|c|c|c|c|c|c|}
\hline \multirow{4}{*}{ Treatments } & \multicolumn{6}{|c|}{ Total microbial count in cfu/g } \\
\hline & \multicolumn{3}{|c|}{ Mace } & \multicolumn{3}{|c|}{ Nut } \\
\hline & \multicolumn{6}{|c|}{ Harvested nutmeg } \\
\hline & $\begin{array}{c}\text { Bacteria } \\
\text { (x 106) }\end{array}$ & $\begin{array}{l}\text { Fungi } \\
(x \text { 103) }\end{array}$ & $\begin{array}{l}\text { Actinomycetes } \\
\text { (x 105) }\end{array}$ & $\begin{array}{c}\text { Bacteria } \\
\text { (x 106) }\end{array}$ & $\begin{array}{l}\text { Fungi } \\
\text { (x 103) }\end{array}$ & $\begin{array}{c}\text { Actinomycetes } \\
(x \text { 105) }\end{array}$ \\
\hline T1 & $3.3 \mathrm{a}$ & $1.3 \mathrm{a}$ & $0.3 \mathrm{a}$ & $1.6 \mathrm{a}$ & $1.3 \mathrm{a}$ & $0.33 \mathrm{a}$ \\
\hline $\mathrm{T} 2$ & $1.6 \mathrm{~b}$ & $1.3 \mathrm{a}$ & $0.0 \mathrm{a}$ & $1.6 \mathrm{a}$ & $0.6 \mathrm{a}$ & $0.0 \mathrm{a}$ \\
\hline T3 & $0.6 b c$ & $0.6 \mathrm{a}$ & $0.0 \mathrm{a}$ & $0.6 \mathrm{a}$ & $1.3 \mathrm{a}$ & $0.0 \mathrm{a}$ \\
\hline $\mathrm{T} 4$ & $0.3 \mathrm{c}$ & $0.6 \mathrm{a}$ & $0.0 \mathrm{a}$ & $0.6 \mathrm{a}$ & $0.6 \mathrm{a}$ & $0.0 \mathrm{a}$ \\
\hline \multirow[t]{2}{*}{ Control } & $1.6 \mathrm{~b}$ & $1.6 \mathrm{a}$ & $0.6 \mathrm{a}$ & $1.3 \mathrm{a}$ & $1.6 \mathrm{a}$ & $0.6 \mathrm{a}$ \\
\hline & \multicolumn{6}{|c|}{ Fallen nutmeg } \\
\hline $\mathrm{T} 1$ & $4.0 \mathrm{~b}$ & $3.0 \mathrm{ab}$ & $0.6 a b$ & $3.3 \mathrm{a}$ & $4.3 \mathrm{a}$ & $1.0 \mathrm{~b}$ \\
\hline $\mathrm{T} 2$ & $2.3 \mathrm{c}$ & $1.6 \mathrm{bc}$ & $0.6 \mathrm{ab}$ & $2.3 \mathrm{ab}$ & $2.3 \mathrm{~b}$ & $0.0 \mathrm{~b}$ \\
\hline T3 & $2.0 \mathrm{c}$ & $1.3 \mathrm{c}$ & $0.6 \mathrm{ab}$ & $2.0 \mathrm{~b}$ & $2.6 \mathrm{~b}$ & $0.3 \mathrm{~b}$ \\
\hline $\mathrm{T} 4$ & $1.3 \mathrm{c}$ & $1.6 b c$ & $0.3 b$ & $1.6 \mathrm{~b}$ & $1.6 \mathrm{~b}$ & $0.0 \mathrm{~b}$ \\
\hline Control & $4.6 \mathrm{a}$ & $3.3 \mathrm{a}$ & $1.6 \mathrm{a}$ & $2.3 \mathrm{a}$ & $2.3 \mathrm{~b}$ & $2.3 \mathrm{a}$ \\
\hline
\end{tabular}

(Values with different superscript differ significantly); The values represent average of three replications; $\mathrm{T}_{1}$ : Sun drying, $\mathrm{T}_{2}$ : Oven drying, $T_{3}$ : Bulb drying, $T_{4}$ : Mechanical drying and Control: Nutmeg without pretreatment but mechanically dried 
Table.6 Effect of drying methods on oil and oleoresin content of nutmeg

\begin{tabular}{|c|c|c|c|c|c|c|c|c|}
\hline \multirow{3}{*}{ Treatments } & \multicolumn{3}{|c|}{ Oil content \% (v/w) } & \multicolumn{4}{c|}{ Oleoresin (\%) } \\
\cline { 2 - 9 } & $\begin{array}{c}\text { Harvested } \\
\text { nutmeg }\end{array}$ & \multicolumn{2}{c|}{ Fallen nutmeg } & \multicolumn{2}{c|}{ Harvested nutmeg } & \multicolumn{2}{c|}{ Fallen nutmeg } \\
\cline { 2 - 9 } & Mace & Nut & Mace & Nut & Mace & Nut & Mace & Nut \\
\hline $\mathrm{T}_{1}$ & $7.28^{\mathrm{c}}$ & $7.93^{\mathrm{a}}$ & $7.26^{\mathrm{c}}$ & $7.96^{\mathrm{a}}$ & $20.13^{\mathrm{bc}}$ & $26.95^{\mathrm{c}}$ & $19.73^{\mathrm{b}}$ & $25.26^{\mathrm{c}}$ \\
\hline $\mathrm{T}_{2}$ & $7.89^{\mathrm{b}}$ & $7.34^{\mathrm{b}}$ & $7.81^{\mathrm{b}}$ & $7.38^{\mathrm{c}}$ & $20.43^{\mathrm{b}}$ & $27.80^{\mathrm{bc}}$ & $19.83^{\mathrm{b}}$ & $27.12^{\mathrm{b}}$ \\
\hline $\mathrm{T}_{3}$ & $7.95^{\mathrm{b}}$ & $7.83^{\mathrm{a}}$ & $7.85^{\mathrm{b}}$ & $7.58^{\mathrm{c}}$ & $19.40^{\mathrm{c}}$ & $27.10^{\mathrm{c}}$ & $19.40^{\mathrm{b}}$ & $26.63^{\mathrm{bc}}$ \\
\hline $\mathrm{T}_{4}$ & $8.40^{\mathrm{a}}$ & $8.06^{\mathrm{a}}$ & $8.25^{\mathrm{a}}$ & $8.10^{\mathrm{a}}$ & $22.40^{\mathrm{a}}$ & $29.09^{\mathrm{a}}$ & $22.00^{\mathrm{a}}$ & $28.90^{\mathrm{a}}$ \\
\hline Control & $8.25^{\mathrm{a}}$ & $7.96^{\mathrm{a}}$ & $8.06^{\mathrm{a}}$ & $7.86^{\mathrm{b}}$ & $21.06^{\mathrm{b}}$ & $28.26^{\mathrm{ab}}$ & $20.46^{\mathrm{b}}$ & $27.56^{\mathrm{ab}}$ \\
\hline
\end{tabular}

Table.7a Sensory evaluation of harvested nutmeg mace dried under different drying methods

\begin{tabular}{|c|c|c|c|c|c|}
\hline Treatments & Colour & Aroma & Appearance & $\begin{array}{c}\text { Overall } \\
\text { acceptability }\end{array}$ & Total score \\
\hline $\mathrm{T}_{1}$ & $6.7(2.0)$ & $7.3(2.70)$ & $5.6(1.45)$ & $5.7(1.25)$ & 25.3 \\
\hline $\mathrm{T}_{2}$ & $7.6(3.1)$ & $7.5(3.00)$ & $6.3(1.90)$ & $7.5(3.45)$ & 28.9 \\
\hline $\mathrm{T}_{3}$ & $6.8(2.35)$ & $6.8(2.15)$ & $7.7(3.70)$ & $7.3(3.05)$ & 28.6 \\
\hline $\mathrm{T}_{4}$ & $8.5(4.55)$ & $8.1(4.05)$ & $8.1(4.25)$ & $8.1(4.10)$ & 32.8 \\
\hline Control & $7.4(3.0)$ & $7.6(3.10)$ & $7.7(3.70)$ & $7.5(3.45)$ & 30.2 \\
\hline Kendall's coefficint & $0.446^{*}$ & $0.235^{*}$ & $0.695^{*}$ & $0.514^{*}$ & \\
\hline
\end{tabular}

Table.7b Sensory evaluation of fallen nutmeg mace dried under different drying methods

\begin{tabular}{|c|c|c|c|c|c|}
\hline Treatments & Colour & Aroma & Appearance & $\begin{array}{c}\text { Overall } \\
\text { acceptability }\end{array}$ & Total score \\
\hline $\mathrm{T}_{1}$ & $6.0(2.35)$ & $7.0(2.55)$ & $5.2(2.20)$ & $4.8(1.75)$ & 23.0 \\
\hline $\mathrm{T}_{2}$ & $6.5(3.20)$ & $7.3(3.20)$ & $5.8(2.85)$ & $6.7(3.55)$ & 26.3 \\
\hline $\mathrm{T}_{3}$ & $6.0(2.50)$ & $6.8(2.35)$ & $6.5(4.00)$ & $6.6(3.65)$ & 25.9 \\
\hline $\mathrm{T}_{4}$ & $7.4(4.55)$ & $7.5(3.65)$ & $6.8(4.30)$ & $7.1(4.20)$ & 28.8 \\
\hline Control & $5.9(2.40)$ & $7.3(3.25)$ & $4.9(1.65)$ & $5.2(1.85)$ & 23.3 \\
\hline Kendall's coefficint & $0.443^{*}$ & $0.156^{*}$ & $0.595^{*}$ & $0.574^{*}$ & \\
\hline
\end{tabular}

\section{Sensory evaluation}

The sensory evaluation was carried out on a nine point hedonic scale using score card for four attributes namely colour, aroma, appearance and overall acceptability. Each character was scored on the scale and the total scores calculated out of thirty six. In case of harvested nutmeg mace highest total sensory score (32.8) was recorded in $\mathrm{T}_{4}$ (mechanically dried) followed by (30.2) in control and least (25.3) in $\mathrm{T}_{1}$ (sun dried).

Highest mean rank for overall acceptability was in $\mathrm{T}_{4}$ (mechanically dried) and least (1.25) in $\mathrm{T}_{1}$ (sun dried) and higher the mean rank better is the quality. Kendall's coefficients of concordance among the judges on all the characteristics were highly significant (Table 7a). In case of fallen nutmeg mace highest total sensory score (28.8) was recorded in $\mathrm{T}_{4}$ (mechanically dried) followed by (26.3) in $\mathrm{T}_{2}$ (oven dried) and least (23.0) in control. Highest mean rank for overall acceptability (4.20) was recorded in $\mathrm{T}_{4}$ (mechanically dried) and least (1.75) in $\mathrm{T}_{1}$ (sun dried). Kendall's coefficients of concordance among the judges on all the 
characteristics were highly significant (Table $7 b)$.

Sensory evaluation of mace showed that mace dried in a mechanical drier is of good quality than in other methods. This could be due to uniform drying of mace at low temperature. Bulb drying and sun drying resulted in bleached appearance of mace hence lowest sensory score for colour was observed in them whereas oven drying resulted in the slight deposition of soot in mace. Pretreatment resulted in washing away of any adherent soil and dirt particles and so good appearance after drying. Harvested nutmeg mace showed higher sensory scores than fallen nutmeg mace because of fresh appearance and wholesomeness. This result is in accordance with the findings of Dandamrongrak et al., (2003) who reported that sensory quality (colour) of blanched banana dried in a heat pump dehumidifier dryer at $50^{\circ} \mathrm{C}$ is greater than un blanched banana.

\section{References}

Chikkanna, G.S. 2008. Development and evaluation of a convective type dryer for nutmeg mace (Myristica fragrans Houtt.) M.Tech (Ag. Eng.) thesis, Kerala Agricultural University, Tavanur, $58 \mathrm{p}$.

Gauniyal, A.K., Anupkumar and Viramani, O.P. 1988. Rauvolfia serpentina- A review. Curr. Res. Med. Arom. Plants. 10(3): 117.

Gopalakrishnan, M. 1992. Chemical composition of nutmeg and mace. J. Spices and Aromat. Crops. 1(1): 49-54.

Gopalakrishnan, M., Thomas, P.P., Bhat, A.V., Varkey, A.G., Menon, N. and Mathew, A.G. 1980. Post harvest technology of nutmeg. In Processing Technology and Marketing:
Proceedings of the Third Annual Symposium on Plantation Crops. Indian Society for Plantation crops. Kasargod, India.

Haldankar, P.M. and Rangwala, A.D. 2009. Nutmeg-a boon spice for Konkan. Spice India, 22: 4-9.

Jayashree, E., Chempakam, B., Zachariah, J. and Alaguselvi, K. 2010. Thin layer drying kinetics of mace (Myristica fragrans Houtt.).

Joy, C.M., Pittappillil G.P and Jose K.P. 2000. Quality improvement of nutmeg using solar tunnel dryer. J. Plantn. Crops, 28(2): 138-143.

Manjusha, A. 2012. Drying and storage studies in Kizharnelli (Phyllanthus amarus Schum. \& Thonn.) M.Sc. (Hort.) thesis, Kerala Agricultural University, Vellanikkara, Thrissur, $88 \mathrm{p}$.

Mehta, R.R., Jain, S., Garg, M. K. and Shinde, A.T. 2005. Comparative evaluation of different drying methods of dry liquorice (Glycyrrhiza glabra). Envt. Ecol., 23(2): 307-310.

Padmapriya, S., Kumanan, K. and Rajamani, K. 2009. Optimization of post harvest techniques for Tinospora cordifolia. Acd. J. Plant. Sci. 2(3): 12-131.

Pruthi, J.S. 1979. Quality Evaluation of Spices III. Analytical pungent principles in black and white pepper-A critical appraisal. Indian Spices. 7(20): 21-23.

Pruthi, J. S. and Krishnamurthy. 1985. Indian Cocoa, Arecanut and Spices J., 8(3): 75-77.

Purseglove, J.W., Brown, E.G., Green, C.L. and Robins, S.R.J. 1981. Spices. Longman. New York. PP: 39-40.

Thangaselvabai, T., Sudha, K.R., Selvakumar, T. and Balakumbahan, R. 2011. Nutmeg (Myristica fragrans Houtt.)-The twin spice-a review. Agri. Review, 32(4): 283-293.

Yuvraj, T. 2007. Studies on the effect of organic inputs and standardization of post harvest techniques on Widelia chinensis (Osbeck) Mcrill. M.Sc. (Hort.) thesis, Tamil Nadu Agricultural University, Coimbatore. 200p.

\section{How to cite this article:}

Naveen Kumar, S., A. Srinivasulu, P. Jacob John and Bharghavarami Reddy, C.H. 2017. Effect of Washing and Drying Methods in the Quality of Nutmeg. Int.J.Curr.Microbiol.App.Sci. 6(2): 464-472. doi: http://dx.doi.org/10.20546/ijcmas.2017.602.052 